\title{
Value-Added Tax On Virtual World Transactions: A South African Perspective
}

Gregory Johnston, University of Pretoria, South Africa Saré Pienaar, University of Pretoria, South Africa

\begin{abstract}
The dawn of the internet age has brought about concepts such as electronic commerce, virtual worlds and digitized products. When consumption tax laws such as value-added tax (VAT) or goods and service tax (GST) were legislated, these concepts were not envisaged. The aim of this article is to determine whether the South African value-added tax (VAT) Act is applicable to transactions occurring in virtual worlds. The article critically analyses section 7(1) of the VAT Act to determine its applicability to transactions occurring in virtual worlds. The benefit of this article will be to highlight the deficiency in the South African VAT Act in dealing with electronic commerce transactions as well as transactions arising in virtual worlds. The study reported here concluded that the South African VAT Act in its current format does not appear to deal with transactions occurring in virtual worlds effectively. Consequently, amendments to existing law should be effected in order to deal effectively with the transactions.
\end{abstract}

Keywords: Value-added Tax; Tax; Virtual Worlds; Electronic Commerce

\section{INTRODUCTION}

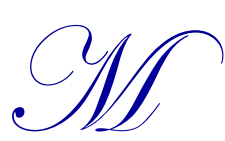

ore people in Africa have access to mobile phones than to clean drinking water. A growing number of people are beginning to use their mobile phones for accessing the internet for varying purposes from social networking to downloading of music and ringtones and to a lesser extent, banking (Hutton, 2011).

As access to internet becomes more prevalent, participation in internet-based activities grows as well. Internet access via broadband becomes available to millions more Americans annually. Internet connectivity has become the norm for most Americans. People do not differentiate between virtual and real life (Terry, 2012). It was estimated that during 2010, virtual goods would generate in excess of seven billion US dollar, and by the year 2014, this figure is expected to be as high as 14 billion US dollar globally (Reisinger, 2010). These booming virtual economies have drawn the attention of a United States (US) Congressional Committee, which investigated how virtual assets and income should be taxed as these virtual economies have millions of users and gross domestic products that rival those of small countries (Reuters, 2006).

It is evident from the above that virtual world economies are growing to the extent that they could begin to represent a significant portion of the world's economy. There is therefore a definite need to investigate the South African value-added tax (VAT) implications of transactions occurring within virtual worlds from the South African context. Although prior research has focused on the South African income tax implications of income earned in virtual worlds (Pienaar, 2010) and the applicability of South African VAT legislation with regard to the supply of digitized products (De Swardt \& Oberholzer, 2006), the South African VAT implications of transactions occurring in virtual worlds has not yet been researched.

VAT is a significant contributor to the South African fiscus, where it has been forecast that VAT will contribute 25.4\% to total tax revenue for the 2011/2012 tax year (National Treasury, 2012). In the event that businesses exploit the fact that there is no specific legislation governing electronic commerce and virtual world transactions, the South African fiscus could potentially lose a significant portion of its revenue derived from VAT. 
It is therefore imperative to consider whether VAT legislation in its current format is sufficient to tax transactions concluded in virtual worlds. This article focuses on the applicability of the current South African VAT legislation to virtual world transactions.

This article will provide a point of departure for the creation of a new body of knowledge, which could be used by the South African Revenue Service (SARS) in developing a strategy to bring transactions occurring in virtual worlds into the VAT net. It is crucial that these transactions be brought into the VAT net in order to eliminate the tax evasion opportunities presented by virtual world transactions. This article could also assist businesses and consumers to identify means of structuring their affairs in order to minimize their liability for VAT.

The article commences with a literature review of South African legislation. The findings are tested through a series of discussions with leading VAT experts in South Africa and a conclusion as to the applicability of the current VAT legislation is reached.

\section{METHODOLOGY}

This article analyzes the current South African VAT legislation in order to establish whether it is sufficient to bring transactions occurring in virtual worlds into the VAT net. The research on which this article is based was conducted in the form of a literature review. The finding of the literature review was then corroborated through a series of discussions with South African VAT experts in order to obtain their opinions with regard to the applicability of South African VAT legislation to transactions occurring in virtual worlds.

\section{LITERATURE REVIEW}

The dawn of the internet age has brought about concepts such as electronic commerce, virtual worlds and digitized products. When consumption tax laws such as VAT or goods and service tax (GST) were legislated, these concepts were not envisaged, and consequently the law needs to be analyzed to ensure that it is applicable to deal with the consequences of these new concepts.

\section{Definitions}

Before analyzing the legislation, it is necessary to define some concepts in order to create the background to the research problem.

\section{Virtual worlds}

A virtual world is a simulated environment in which users interact with each other in the form of computer graphic-generated characters known as avatars. An example of such a virtual world is Second Life, which specifically encourages the creation of wealth within the virtual economy by promoting creativity and entrepreneurial activity. This is evident through Second Life's terms of service agreement, which specifically provides for participants to retain their intellectual property rights over their creations within the game (Miano, 2007).

By allowing participants to retain their intellectual property rights in their virtual creations, it is evident that Second Life has created an environment in which entrepreneurial activity is encouraged. People have an incentive to create infrastructure or products from which they can derive value. This value can be retained within the virtual world or cashed out in real-world money by exchanging Linden dollars for US dollars (Lederman, 2007). The implication of being able to exchange a virtual world currency for a real-world currency such as the US dollar is that the currency, goods and services have a corresponding real-world monetary value. Participants in these virtual economies can therefore create real-world wealth through their participation in the virtual economy (Miano, 2007). 


\section{Digitized products}

Chau and Hui (2002) define digital products as "any goods or services that can be digitized (converted into a binary format)." Oberweis, Pankratius and Stucky (2007) define digital products as "[A] bunch of properties or features which are constituted by artifacts that are either digitized or produced electronically."

\section{Analysis of current legislation}

In order for a transaction to attract VAT in terms of section 7(1) (a) of the South African Value-Added Tax Act 89 of 1991 (VAT Act), there should be a supply of goods or services by a vendor in the course or furtherance of an enterprise. In order to conclude that the VAT Act is applicable to virtual world transactions, all of the above components of the said section should be complied with. It is therefore necessary to analyze each of these components individually.

Supply

The definition of a supply in Section 1 of the VAT Act includes a sale, a rental agreement, an installment sale agreement and all other forms of supply, whether voluntary, compulsory or by operation of law, irrespective of where the supply is effected (De Swardt, Jordaan, Koekemoer, Stiglingh, Van Schalkwyk, \& Wilcocks, 2009). The definition of a supply is very wide. This results in almost any transaction that could possibly take place between two businesses meeting the definition of a supply. Transactions taking place in virtual worlds would therefore meet the definition of a supply due to the breadth of the definition.

\section{Goods or services}

Goods are defined in Section 1 of the VAT Act as corporeal movable things, fixed property, any real right in any such thing or fixed property and electricity (Huxham \& Haupt, 2011). Through analysis of the definition of goods in section 1 of the VAT Act, it is apparent that digitized products cannot be classified as goods. To be classified as goods in terms of this definition, a product has to be a physical object or a real right in such object (De Swardt \& Oberholzer, 2006).

Goods supplied in a virtual world are digitized products as they are supplied in a digital format as envisaged by the definition of a digitized product. Consequently, they would not meet the criteria of being a corporeal movable thing, fixed property, any real right in any such thing or fixed property and electricity as envisaged above. Consequently, these items would therefore be excluded from the definition of goods.

Services are defined in section 1 of the VAT Act as anything done or to be done. This includes the granting, assignment, cession or surrender of any right as well as the making available of any facility or advantage. The application of this definition results in a wide range of transactions constituting the supply of a service. Accordingly, if something is not classified as goods, then it is a service for VAT purposes (Huxham \& Haupt, 2011).

Transactions taking place in a virtual world can therefore be classified as services for purposes of the VAT Act. This assertion is further supported by a survey conducted in 2006 amongst VAT specialists in South Africa, which indicated that the majority of the respondents were of the opinion that digitized products should be classified as services (De Swardt \& Oberholzer, 2006).

From an international perspective, the assertion that digitized products should be classified as services is further supported by New Zealand's stance on their goods and services tax with regard to e-commerce. Digital products sold over the internet are treated as services for goods and services tax purposes (Inland Revenue New Zealand, 2011).

Transactions occurring between participants in a virtual world where the transaction comprises of the sale of a product or service in return for a virtual world currency should, according to the Swedish Tax Agency's ruling, be considered to be sale of electronic services if the virtual currency is exchangeable into a valid real-world currency (Lehdonvirta, 2008). 
Based on the above, it is evident that transactions taking place in virtual worlds should be classified as services for purposes of the VAT Act.

By a vendor

Before a supply can attract VAT, it must have been made by a vendor. A vendor is any person who is registered for VAT or is required to be registered for VAT (Huxham \& Haupt, 2011). In terms of Section 23(1) of the VAT Act, a person is obliged to register for VAT if his or her taxable supplies exceed one million rand (equivalent to approximately US\$130 000) per annum. In terms of Section 23(3)(d) of the VAT Act, a voluntary registration may be made by persons making taxable supplies exceeding R50 000 (equivalent to approximately US\$ $6500)$ per annum.

The question would then arise as to how the value of these supplies would be determined in order to evaluate whether the registration criteria have been met. The virtual world transactions would be priced in Linden dollars, in the case of Second Life for example. Linden dollars are exchangeable for US dollars (Lederman, 2007). By exchanging the Linden dollars for US dollars and ultimately the US dollars for South African rand, it will be possible to determine whether the criteria of R50 000 or one million rand has been reached. It therefore follows that it is possible to determine whether the criteria for VAT registration have been met. Consequently, a virtual world participant can meet the criteria for VAT registration and therefore be a VAT vendor.

\section{Course or furtherance of an enterprise}

In order for a supply to attract VAT, it should be made in the course or furtherance of an enterprise (De Swardt et al., 2009). The VAT Act defines an enterprise as any enterprise or activity, carried on regularly or continuously in South Africa or partly in South Africa. The last element of the definition of enterprise presents a problem, as the place of supply is not obvious when dealing with transactions arising in virtual worlds.

In order for the definition of a supply to be complied with, the place of supply needs to be in South Africa, or partly in South Africa, as discussed above. The South African VAT system is unusual in comparison to other VAT jurisdictions in that it does not use specific place of supply rules to determine whether a supply is subject to VAT in South Africa (De Koker and Kruger, 2010).

A problem arises due to the fact that VAT is a consumption tax. Consumption taxes were developed under the premise that the product is physically present within the specific tax jurisdiction. E-commerce has, however, eliminated the need for physical presence of a product (De Swardt \& Oberholzer, 2006). Products or services can therefore be supplied directly to a person in the comfort of his or her home, directly to his or her personal computer by a supplier sitting anywhere in the world.

A survey conducted among VAT specialists in South Africa in 2006 revealed that there is great uncertainty regarding whether a foreign supplier who supplies digitized products to a person located in South Africa is carrying on an enterprise in South Africa. Only half the respondents were of the opinion that the foreign supplier would be carrying on an enterprise in South Africa. This lack of consensus indicated an uncertainty regarding whether the VAT Act creates an obligation for a foreign supplier to charge South African VAT on the supply and to remit such VAT collected to the South African Revenue Services (De Swardt \& Oberholzer, 2006).

Consumption tax rules for cross-border electronic trade should result in taxation being payable in the jurisdiction in which the consumption of the product or service takes place. Where products are electronically delivered via the internet, there is no physical address for the supplier to rely upon. This creates difficulties for revenue authorities as well as suppliers (Organisation for Economic Co-operation and Development, 2001). From the research above, it is evident that this is not achieved by the VAT Act in its current format.

From the above literature review, it is evident that for a transaction to be subject to South African VAT, such transaction must have occurred in South Africa. However, the nature of virtual world transactions is that they can originate from anywhere in the world, even though the item may be consumed or utilized in South Africa. As 
noted by the Organisation for Economic Co-operation and Development (OECD) above, tax rules for cross-border electronic trade should result in taxation being payable in the jurisdiction in which the consumption of the product or service takes place. Thus if a digitized product, purchased in a virtual world is consumed or utilized by a South African consumer based in South Africa, that transaction should be subject to VAT in South Africa.

From the above literature review, it is evident that a transaction occurring in a virtual world would comply with the VAT Act's requirements of being a supply of a service by a vendor. However, the requirement of being in the course or furtherance of an enterprise is problematic in that it requires that the supply has to be made in South Africa. Since there are no specific place of supply rules, which deem the place of supply to be in South Africa and consequently result in the supply being made in South Africa, it can be concluded that section 7(1)(a) does not bring transactions occurring in virtual worlds into the VAT net.

There is however one more provision in the South African VAT act which needs to be considered before it can be concluded that the VAT Act is incapable of taxing virtual world transactions. Section 7(1)(c) of the VAT Act specifically provides that VAT is levied on the supply of any imported services. From the literature review above, it was determined that virtual world transactions would fall under the definition of a service, and consequently this section should be considered with regard to virtual world transactions.

\section{Imported services provisions}

Section 7(1)(c) of the VAT Act specifically provides that VAT is levied on the supply of any imported services. Section 1 of the VAT Act specifically defines an imported service as "a supply of services that is made by a supplier who is resident or carries on business outside the republic to a recipient who is a resident of the Republic to the extent that such services are utilised or consumed in the Republic otherwise than for the purpose of making taxable supplies". In order for the imported service provisions to apply, the foreign supplier may not be registered for VAT in South Africa and the consumer should not intend to use the goods for the making of taxable supplies. When this is the case, the South African consumer is liable to account for VAT on the imported service, if the consumer is not registered for VAT in South Arica (Steyn, 2010). The burden to account for VAT under the imported services provisions falls on the consumer.

Digital products which are not intended to be used for the making of taxable supplies in South Africa, acquired from a foreign supplier, who is not a VAT-registered supplier in South Africa, will be subject to VAT in South Africa. The recipient of the service or digital product is obliged to account for the VAT on the transaction by paying the VAT over to SARS within 30 days of receiving the invoice from the supplier or paying for the product or service. SARS is therefore reliant on the honesty of the taxpayer to declare and remit the VAT (Naicker, 2010). There is therefore great potential for VAT leakage as the collection for VAT on supplies made in this manner is reliant on the honesty of the consumer.

Under these provisions, the consumer is required to contact a SARS branch, declare the purchase, and remit the resultant VAT on the purchase to SARS. This mechanism relies heavily on the honesty of the consumer to collect taxes. The risk of non-collection of taxes is very high under this mechanism (Steyn, 2010).

A reverse charge or self-assessment mechanism for the collection of taxes arising on supplies made by businesses to consumers is not considered appropriate (Organisation for Economic Co-operation and Development, 2003). Where countries consider it necessary a registration system is the most practical system to ensure the collection of taxes on these transactions. This system requires the vendor to collect tax on cross-border transactions. It is clear from this statement that OECD is of the opinion that a mechanism such as the one that South Africa is currently employing to collect VAT arising on imported services is not appropriate.

It is evident that imported services provision is applicable to virtual world transactions. However, this system relies on the honesty of the consumer of the products and is very difficult to enforce. A registration-based system where suppliers of a product have an obligation to account for and pay over VAT as per the OECD recommendation above is a more reliable method of ensuring that VAT is levied and collected on transactions that should be subject to VAT. The fact that a self-assessment mechanism is in place does not seem to be sufficient to 
enforce the collection of a tax that is responsible for $25.4 \%$ of the country's tax collections as was noted in the introduction to this article.

\section{What the experts said}

In order to test the findings of this research, a series of discussions were held with South African VAT experts. Four experts who were selected to find a balance between academia and commerce were contacted. A brief discussion with these experts as summarized in the findings below was held.

With regard to the place of supply of electronic commerce transactions, all of the experts were of the opinion that current South African VAT legislation does not specifically address the place of supply of electronic commerce transactions.

Regarding whether electronically supplied products do not meet the definition of goods as per the VAT Act and should consequently be classified as services, all of the experts were of the opinion that such products do not meet the definition of goods and therefore should be classified as a service. One of the experts added to this by stating that the definition of goods should be amended to include electronically supplied goods.

Regarding whether a foreign supplier supplying digitized products via e-commerce will not be subjected to VAT in South Africa, all of the experts agreed with this statement. All of the experts also stated, however, that the recipient of the digitized product in South Africa would be liable to declare the VAT and remit such VAT to SARS under the imported service provision. One of the experts commented further that this self-assessment mechanism is not a very effective mechanism, whilst another of the experts stated that tracking or enforcing this mechanism is a problem.

The final question posed to the experts was whether they were of the opinion that on an overall basis, the current VAT Act addresses electronic transactions sufficiently. All the experts were of the view that the VAT Act in its current format does not address e-commerce transactions sufficiently. The following major flaws were identified by the experts:

- $\quad$ More guidance is required on where place of supply is versus where services are rendered;

- $\quad$ Place of supply should be rectified to address e-commerce;

- The meaning of goods should be rectified to include electronic goods.

\section{CONCLUSION}

The main objective of this article was to highlight the findings of research into the applicability of South African VAT legislation to transactions occurring in virtual worlds. The article comprises of a detailed literature review, which had as its point of departure an analysis of section 7(1) of the VAT Act to determine its applicability to transactions occurring in virtual worlds.

On analyzing section 7(1) of the VAT Act, it was evident that, in order for transactions to fall within the VAT net in South Africa, there should be a supply of goods or services by a vendor in the course or furtherance of an enterprise. From the analysis of the literature available, it was concluded that there is a supply of services by a vendor. However, the "course or furtherance of an enterprise" component is problematic. If one analyzes this component, there is a requirement that the transaction must take place in South Africa or partly in South Africa. This poses a problem as it is clear from the literature review that the VAT Act is not specific regarding the place of supply of transactions occurring in virtual worlds.

The applicability of the imported services provision was also tested. It was concluded that, on strict interpretation of this provision, it would be applicable to virtual world transactions; however, it is not considered the best method of collecting VAT. The findings of the literature review were corroborated by discussions held with VAT experts. 
The current VAT Act was issued in 1991, long before e-commerce, digital products and virtual worlds were even a possibility. The problem identified above could be dealt with by amending the existing legislation to specifically deal with the place of supply of digitized products supplied through e-commerce and in virtual worlds. The definition of goods should also be amended to include digitized products and consequently virtual goods.

This article did not consider the intricacies of connecting the participant in a virtual world to an avatar. It also did not consider the mechanisms or amendments that are required to ensure that virtual world transactions are captured in the VAT net. Future research could focus on these areas.

\section{AUTHOR INFORMATION}

Gregory Johnston, M Com student in the Department of Taxation at the University of Pretoria, South Africa. Greg is a chartered accountant (SA). E-mail: gjjohnston@telkomsa.net

Saré Pienaar, senior lecturer in the Department of Taxation at the University of Pretoria, South Africa. Currently involved in various research projects in tax, focusing on human behavior regarding taxation as well as the applicability of tax policy in terms of the internet transactions. E-mail: sare.pienaar@up.ac.za (Corresponding author)

\section{REFERENCES}

1. Chau, P. \& Hui, K. (2002). Classifying digital products. Communications of the ACM, 45(6), 73-79.

2. De Koker, A. \& Kruger, D. (2010). VAT in South Africa, chapter 3.1. Retrieved from: http://butterworths.up.ac.za/nxt/gateway.dll?f=templates $\$$ fn=default.htm $\$$ vid=mylnb:10.1048/enu

3. De Swardt, R. \& Oberholzer, R. (2006). Digitised products: how compliant is South African value-added tax? Meditari: Research Journal of the School of Accounting Sciences, 14(1), 15-28.

4. $\quad$ De Swardt, R., Jordaan, K., Koekemoer, A., Stiglingh, M., Van Schalkwyk, L. \& Wilcocks, J. (2009). Silke: South African income tax. Durban: LexisNexis.

5. Huxham, K. \& Haupt, P. (2011). Notes on South African income tax. Roggebaai: H \& H Publications.

6. Hutton, J. (2011). Mobile Phones Dominate in South Africa. Retrieved from: http://blog.nielsen.com/nielsenwire/global/mobile-phones-dominate-in-south-africa/

7. Inland Revenue New Zealand. (2011). E-commerce and tax: e-commerce and GST. Retrieved from: http://www.ird.govt.nz/ecommerce-tax/ecommerce-gst/business-australian-ecommerce-gst.html\#0

8. Lederman, L. (2007). "Stranger than fiction": taxing virtual worlds. New York University Law Review, 82(6), 1620-1672.

9. Lehdonvirta, V. (2008). Sweden moves to tax in-game transactions. Retrieved from: http://virtualeconomy.org/blog/sweden_moves_tax_-game_transactions

10. Miano, T. (2007). Virtual world taxation: theories of income taxation applied to the Second Life virtual economy. Retrieved from: http://works.bepress.com/cgi/viewcontent.cgi?article=1000\&context=timothy miano

11. Naicker, K. (2010). The VAT implications of e-commerce. TAXtalk, January/February 2010: 8-9.

12. National Treasury \& South African Revenue Services. (2012). Budget 2012 Highlights. Retrieved from: http://www.treasury.gov.za/documents/national\%20budget/2012/guides/Budget\%20Highlights\%202012.pd $\underline{\mathrm{f}}$

13. Oberweis, A., Pankratius, V., Stucky, W. (2007). Product lines for digital information products. Retrieved from: http://0-www.sciencedirect.com.innopac.up.ac.za/science/article/pii/S0306437906000809

14. Organisation for Economic Co-operation and Development. (2001). Consumption tax aspects of electronic commerce: A report from working party no. 9 on consumption taxes to the committee on fiscal affairs. Retrieved from: http://www.oecd.org/dataoecd/37/19/2673667.pdf

15. Organisation for Economic Co-operation and Development. (2003). Consumption tax guidance series: Verification of customer status and jurisdiction. Retrieved from: http://www.oecd.org/dataoecd/25/31/17851117.pdf

16. Pienaar, S. (2010). South African income tax implications for income earned in virtual worlds. Journal of Applied Business Research, 26(2), 47-68. 
17. Reisinger, D. (2010).Virtual goods revenue to hit $\$ 7.3$ billion this year. Retrieved from: http://news.cnet.com/8301-13506 3-20022780-17.html?tag=mncol;2n

18. Reuters, A. (2006). US congress launches probe into virtual economies. Retrieved from: http://secondlife.reuters.com/stories/2006/10/15/us-congress-launchs-probe-into-virtual-economies

19. Steyn, T. (2010). VAT and e-commerce: still looking for answers? South African Mercantile Law Journal, 22:230-258.

20. South Africa. 1991. South African Value-Added Tax Act 89 of 1991. Acts online. [Online] Available from: http://www.acts.co.za/vat/index.htm Date of access: 25 September 2011.

21. Terry, A. (2012). Got broadband? Access now extends to 94 percent of Americans. Retrieved from: http://www.csmonitor.com/USA/Society/2012/0824/Got-broadband-Access-now-extends-to-94-percent-ofAmericans 